\title{
ILCEA
}

Revue de l'Institut des langues et cultures

d'Europe, Amérique, Afrique, Asie et Australie

$46 \mid 2022$

Refuges identitaires numériques

\section{Young Women, Social Media and Antigypsyism in Spain: An Experience of an Online Workshop with Roma Girls and Women}

Jeunes femmes, médias sociaux et antitsiganisme en Espagne : expérience d'un atelier en ligne avec des filles et des femmes Roms

\section{Cilia Willem and Gabriela Marques Gonçalves}

\section{OpenEdition}

\section{Journals}

Electronic version

URL: https://journals.openedition.org/ilcea/14853

DOI: 10.4000/ilcea.14853

ISSN: 2101-0609

\section{Publisher}

UGA Éditions/Université Grenoble Alpes

Printed version

ISBN: 978-2-37747-331-1

ISSN: 1639-6073

\section{Electronic reference}

Cilia Willem and Gabriela Marques Gonçalves, "Young Women, Social Media and Antigypsyism in Spain: An Experience of an Online Workshop with Roma Girls and Women", ILCEA [Online], 46 | 2022, Online since 02 March 2022, connection on 11 March 2022. URL: http://journals.openedition.org/ ilcea/14853 ; DOI: https://doi.org/10.4000/ilcea.14853

This text was automatically generated on 11 March 2022.

(c) ILCEA 


\title{
Young Women, Social Media and Antigypsyism in Spain: An Experience of an Online Workshop with Roma Girls and Women
}

\author{
Jeunes femmes, médias sociaux et antitsiganisme en Espagne : expérience d'un \\ atelier en ligne avec des filles et des femmes Roms
}

Cilia Willem and Gabriela Marques Gonçalves

\section{Introduction}

1 Social media such as Twitter and Facebook are currently sites where right-wing (political) groups in Spain find easy ways to spread organised and random hate speech towards minority groups, among which the Roma community. However, members of these groups, especially the younger generations, are equally learning how to protect themselves from racist and sexist online attacks, raise their voices and make their reality more visible, creating counter-narratives against hate speech and making the internet a safer space for themselves.

2 This article aims to present the experience of an online workshop with young Romani women about the use of social media. This activity was part of the project "Narratives to combat Antigypsyism: the voice of Romani women from an intersectional approach", developed during 2020 and led by Rovira and Virgili University (Spain). This project was funded by the Romani Culture Chair of Alicante University in its annual open call for projects related to the Romani community.

3 The main activity of the project was a practical workshop for young Romani women to exchange ideas and tools in their fight against Antigypsyism on social media. Some concerns about internet safety and the experiences of hate speech and online harassment shared by female Romani activists in Spain had appeared in a previous field 
research with the Romani population in Catalonia (Marques-Gonçalves, 2019), and made us aware of the need to create a space where Romani women could come together in a safe space where their voices would be heard. There were also previous reports with data related to the issue of racism in mainstream media, such as "PPeriodistas contra el racismo? La prensa española ante el Pueblo Gitano" (Journalists against racism? The Spanish press before the Romani people), produced annually by Unión Romani, and Informative Antigypsyism ${ }^{1}$, produced by Rromani Pativ.

Therefore, we realized the importance of training the participants in the construction of their own narratives about the Romani people in the fight against Antigypsyism. To understand the importance of the right to speak among minority groups, it is necessary to consider that this act "is not restricted to the act of emitting words, but it includes the power of existing" (Ribeiro, 2017: 64). The existence here has the meaning of having their rights guaranteed. This includes the reflection that the capacity of interpreting given technologic systems and their use in the production of their own narratives (digital storytelling) can not be a privilege of few people.

5 These narratives produced by the Romani population are a contribution to resisting the stereotypes historically portrayed by mass media, which on one side invisibilize this group and on the other insist on their folklorization or their link to petty crime and conflict (Willem, 2010; Marques-Gonçalves, 2019; Oleaque, 2014). This portrayal is sometimes eventually internalized by the members of this community. One way to fight these negative stereotypes is producing positive images or remembering Romani references or role models in different fields. Considering the lack of space and/or interest in mass media, the internet and, more specifically, social media are an accessible space to constitute these narratives.

6 The new media are then seen as resistance and "social stubbornness" (MarquesGonçalves, Dourado \& Reis, 2010), if we consider that many Romani do not accept the stereotypical portrayal of them. These tools are useful not only in the fights related to the symbolic field, but also to demand and guarantee better social conditions related to housing, health, education and work. Therefore, it is necessary to make a critical reflection about them, showing the advantages and disadvantages of social media and the internet.

\section{Online hate speech, sexism and Antigypsyism}

7 As a specific form of structural racism, Antigypsyism becomes evident in many contexts such as in political, educational, and media institutions. As the internet is being increasingly used as a tool to share discourses, contents, and opinions in the last decades, hate speech has also increased in the online environment. According to a recent document from the European Commission about the inclusion of Roma people, one of the biggest challenges in confronting antigypsyism in Europe is the "high incidence of manifestations of hatred such as bullying, hate speech, including in online and offline media and the public discourse, as well as violent hate crimes" (European Commission, 2018: 5). Therefore, the same document alerts to the importance of implementing specific measures to "effective monitoring, prevention and fight against antigypsyist hate speech in particular online and in the public and political discourse" (European Commission, 2018: 10). 
8 The punishment for hate speech for ethnic reasons keeps on existing without clear legislation that determines the exact scope, accountability, and responsibilities for those acts (Samuli, 2010). Such discourses promote hatred towards a person or a group of people, followed by hostility, rejection, and expressions of destroying or doing harm to the people that are targeted (Parekh apud Samuli, 2010). The Romani people are one of the ethnic groups that are often victims of hate speech, which at best is one of the elements of discrimination, and at worst entail in real attacks or (institutional) violence against them. In the case of Romani women, they have to face not only antigypsyism, but also sexism. On the one hand, Romani women are especially vulnerable to negative representation and stereotyping about Roma in the media; on the other hand these stereotypes are often gendered and/or linked to certain sexual traditions or practices in Romani communities.

9 For all these reasons, our online training was based on an intersectional view of the problems of discrimination against Romani women. Originally derived from feminist thought, the Theory of Intersectionality argues that different identity markers such as gender, class or race cannot be seen separately, but rather leads to multiple discriminations of racialized, poor, homosexual women, etc. (hooks, 2000; Hill, 2000). Thus, intersectionality is a qualitative analytical framework that specifically addresses the experiences of people who are subject to multiple forms of subordination and discrimination within society. For the context of this project, the intersectional perspective meant recognizing that young Romani women can suffer multiple discriminations, both from within and from outside their communities, when trying to access education, citizen participation or employment. These multiple barriers are often due to a lack of resources, the stigma of their origin, for being women, or all at the same time. In previous research we already analysed the online profiles of Romani feminism, showing examples of intersectional feminist struggle in the Romani communities in Spain (Willem; Marques-Gonçalves, 2021).

10 Interseccionality is recognized by the European Parliament, stating in a resolution of 2011 that Romani women "regularly face multiple and intersectional discrimination and are disadvantaged not only in comparison with majority women, but also in comparison with ethnic minority men, and are at particular risk of social exclusion" (European Parliament, 2011). Another resolution from 2013 says Romani women "have limited access to employment, education, health, social services and decision-making" and "are often victims of racism, prejudice and stereotypes that have a negative impact on their real integration" (European Parliament, 2013).

11 The lack of clearness about legislation related to hate speech and their application is even more complex in the digital context. This creates the opposition of discourses that are part of communicational practices and contemporary narratives. Digital technologies are thus re-interpreted on one hand by Romani groups and on another hand by hate culture, influencing directly the symbolic exchanges and the circulation of information on the internet. 


\section{Internet as the focus of the workshop and as the main tool to conduct it}

12 The project was initially focused on social media, as the reach of these tools in the current context is broad and especially appealing to youngsters. According to oleaque and Moreno (2017), the use of social media with a "horizontal transmission" could give a new meaning to the fight against the discrimination in the Romani representation. We also considered the participative nature of the digital environment, fostering the construction of narratives closer to our life experiences, which could transform the way we comprehend and interpret the world, we act and how we treat each other (Murray, 2003: 10).

13 On the other hand, we felt it was important to recognize the limits of this environment and help create consciousness about the security measures needed for a more effective use of these tools, considering the internet is far from being a space where citizenship is really equal. Furthermore, the simple possession of a digital device does not guarantee the social empowerment needed for a construction of narratives that fight, for instance, Antigypsyism. Our initial idea was, therefore, to organize face-to-face workshops with young Romani women from Barcelona and surroundings, and use social media on the go.

However, due to the Covid-19 pandemic and the strict lockdown measures taken by the Spanish government during the first months of the health crisis, we had to replan the workshop and adapt it to an entirely online format. Consequently, the internet became not only the focus of the workshop, but also the main tool to conduct it. The main concerns were how to keep the interest and engagement of the participants during six consecutive sessions and motivate them to participate in the debates and exercises in a collaborative work dynamic. Six months into the lockdown in Spain, we considered that on one side the participants would be more familiar with the online tools, but on the other side they could be tired or weary of this kind of interaction. Therefore, we tried to construct an environment that was open and flexible, enabling us to adapt and replan the structure of the workshop according to participants' needs. Moreover, we tried to facilitate the interaction among the participants in a way they could feel themselves as part of a group, since the majority of them had not met one other. In this way, they could also learn from each other and not only from the trainers or the facilitator.

\section{Methodology: action-research}

This training action is based on the idea of Freire (1977) that all humans are capable of taking decisions that transform their environment rather than adapting to it. Therefore, we thought of a methodology that could contribute to this transformation, acting on reality in a critical way and with commitment (Freire, 1977). In this process, dialogue is the only key to construct empowerment and autonomy. And what we want with the dialogue is "the problematic confrontation of that very knowledge in its unquestionable relationship with the concrete reality in which it is engendered, and on which it acts, in order to better understand, explain, and transform that reality" (Freire, 1977: 52). 

face format in Barcelona. The idea was to invite Romani activists to tell their experience using social media and expert facilitators to explain how the different social media work and how to use different languages to construct narratives. The sessions were divided in these topics: activism and hate speech on the internet; safe use of the internet; uses, tools and potentials of social media; construction of narratives on the internet; and, finally, conclusions and evaluations.

\section{The advantages of an online format}

The advantage of adapting the workshop to an online format was that we could involve participants from all over Spain. The first thing we did was talk with youngsters which were our target group and other people involved in training the Romani people. The 
network we had from previous projects helped us to contact them, explain the project and ask for suggestions about the new format. After that, we could define the time and the days to carry out the sessions respecting the deadline to finalize the project and the other activities we had to do. They also helped us to think about some practical activities and discussions within small groups. This shows the importance of having a previous network and direct contacts with gatekeepers, in order to construct the training phase of the project with the final target group.

As online activities were becoming increasingly common in daily life, and there were many options of video platforms, we decided to use a video conferencing tool our target group was familiar with, was easy to use, accessible as a webtop application, and had the technical affordance of creating break-out rooms for participants to work in pairs or small groups.

We decided to reduce the duration of each session, keeping six meetings of two hours each and to propose some activities to be done individually. This decision was based on the idea that long online sessions would be tiring and unproductive, and that we had to keep the interest of all participants in the workshop until the last session, i.e. for three weeks.

Another decision was not to keep the same trainer for more than one hour to make it more dynamic. Therefore, we tried to have two trainers per session, except in the first and last meetings, which we used to present the project, the team, the facilitator, the trainers and how the workshop would be organised, and finally to evaluate and finish the workshop.

\section{Mediating the process}

The facilitator was the person responsible to link the contents of the different training sessions with experts and to attend to doubts and questions of participants. This function demands knowledge about the Romani culture and history, amongst others the reality of Antigypsyism, in order to select the appropriate trainers, explain the aims of the workshop and organize all the contents. This is important to create meaningful dynamics for the participants since "an activity becomes interesting or not only by the meaning of what it represents" (Brisola, 2006: 5). The participants have to recognize the functionality of what they are learning, awakening curiosity in them.

Moreover, it is necessary to create a welcoming environment to motivate and facilitate the participation in a confident way. This enables the facilitator to clarify information during the sessions or after the meetings. Therefore, this person was also responsible for keeping in touch and building a community with participants between sessions. It is important to pay attention to every issue raised or commented on by participants, as it may offer hints and ideas about their interests and needs.

\section{Realizing the training}

After choosing and involving the trainers for each session, we started to promote the workshop in order to receive participant applications. To do this, we used our social media (Facebook, Instagram and Twitter) and shared the form with information about how to sign up and who were our target group. Some members of the advisory committee of the project helped to share it on their social media and through their 
networks as well. In almost one month of enrollment we received inscriptions from 33 candidates, some of whom were not part of our target group. Finally, we started the workshop with 19 Romani female youngsters.

It was agreed that creating a chat group could be useful during the workshop. In this group, we shared not only information about the workshop, but also contents and events related to the Romani people in Spain. In the first days of the group's existence, the participants suggested exchanging their profiles on social media as to keep in touch and support each other.

At the end of the workshop, in the last session, some of the participants presented their proposals to construct counter-narratives about the Romani people in Spain. One proposal, for example, was carried out on Instagram during the previous weeks, and consisted of a campaign called "\#noparecesgitanx" (You don't look like a Roma), which referred to the typical sentence many Roma have to hear, due to the fact they do not fit in the stereotypes constructed by the majority society: you don't look like a Roma because you wear glasses, you don't look like a Roma because you read science fiction books, you don't look like a Roma because you are studying medicine, etc.

\section{Results and feed-back of participants}

30 In the last session we also carried out a collective evaluation of the workshop. Apart from the fact that the majority of the participants finished the training and accepted the activities we proposed, we could also notice that they had constructed an affective relationship with each other. One example was the interaction on social media not only with the facilitator, but also between the participants, who had never met each other before the workshop.

31 In the anonymous evaluation, some of them believed that the workshop could have had more sessions or they would like to participate in future workshops, deepening their knowledge of the same subject or approaching other issues or tools such as feminism and education. They also said they would recommend the workshop to other people.

\section{Conclusions}

This experience helped us to construct knowledge together with women that were different, but equal (Brandão, 2005). One result of the specific way the workshop was carried out is related to the feeling of belonging to a group. A few months after the end of the project, some youngsters who took part on it created a group on a messaging app adding many other Romani girls and women and decided to start a profile on Instagram called @shukaripen, defined as a "circle of Romani women united by their diverse voices", a space to practice phenjalipen, the Romanó word for sisterhood.

Moreover, after the end of the workshop, we produced a guide ${ }^{2}$ for those who wanted to repeat the experience of the project reaching even more people who may be interested in this subject. The experience was shared in a meeting of the Rromani Pativ project and we were also invited to take part as trainers in an online course ${ }^{3}$ organized by a Romani NGO.

34 It is important to highlight that in this project the digital inclusion and the command of these tools are designed from the perspective of social inclusion and 
intersectionality, considering that the main aim is to fight sexism and antigypsyism on the internet. Consequently, it is inevitable to talk about inequalities in many other sectors such as housing, education, work and health.

\section{BIBLIOGRAPHY}

BRISOLA Elisabette (2006), “A mediação pedagógica: suas relações e interdependências”, Annals of SBIE XVII, <https://www.br-ie.org/pub/index.php/sbie/article/view/470>, <http://dx.doi.org/ 10.5753/cbie.sbie.2006.101-110> (14 March 2021).

FreIRE Paulo (1977), Extensão ou Comunicação?, Rio de Janeiro: Paz e Terra.

GómEZ Jesús et al. (2007), Metodología comunicativa crítica, Barcelona: El Roure Ciencia.

MARQUes-GonçALVEs Gabriela, Dourado Maiara, ReIs Nilton José (2010), “Web TV Magnífica Mundi: novas tecnologias pelo direito à comunicação", Annals of XII Congresso de Ciências da Comunicação na Região Centro-Oeste, Goiânia.

MARQUES-GonçALVES Gabriela (2019), Medios de Comunicación y Cohesión Social: Consumo mediático y cultural de la población gitana de Cataluña (Tesis Doctoral), Universidad Autónoma de Barcelona, Cerdanyola del Vallés.

MARQUES-GonÇAlves Gabriela (2020), "Pesquisa participante e comunicação dialógica: A experiência com as comunidades ciganas da Espanha", Revista de Comunicaçção Dialógica (3), 34-50, $<$ https://doi.org/10.12957/rcd.2020.50867>.

MARQUeS-GonçAlves Gabriela, Willem Cilia (2021), "Lucha feminista gitana en España, lucha interseccional: el combate contra el Antigitanismo en las redes sociales en España", Revista de Investigaciones Feministas, 12(1), 127-143.

MURRAY Janet (2003), Hamlet no Holodeck - o futuro da narrativa no ciberespaço, São Paulo: Itaú Cultural, Unesp.

OLEAQUE Joan M. (2014), Los gitanos en la prensa española - Variación y reiteración de los planteamientos de los diarios ABC, El Páis y La Vanguardia en la representación de los gitanos como grupo (1981-2010) (Tesis Doctoral), Universitat de València, Valencia.

OlEAqUE Joan M., MoRENo Carolina (2017), “Del estereotipo gitano en la prensa de referencia al 'Yo no soy trapacero' de las redes sociales. Caso de estudio sobre la imagen y la representación mediática de una minoría étnica", Revista Sistema (246), 81-96, Madrid.

OliveIRA Rosiska DARCY DE, OLIVEIRA Miguel DARCY DE (1985), "Pesquisa social e ação educativa: conhecer a realidade para poder transformá-la”, C. R. Brandão (org.), Pesquisa Participante (5a edição), São Paulo: Editora Brasiliense.

PERUZzo Cicilia (2008), "Observação participante e pesquisa-ação”, J. Duarte, A. Barros (org.), Métodos e técnicas de pesquisa em comunicação, São Paulo: Atlas.

RiBEIRo Djamila (2017), o que é lugar de fala?, Belo Horizonte: Letramento. 
SAMULI Lari (2010), Hate speech against the Roma in Romania: Discourse Analysis on Three Romanian

Newspapers' Internet Forums (Master's Thesis), Helsinki University, Helsinki.

Willem Cilia (2010), 'Roots and Routes' - Young people from diverse ethno-cultural backgrounds

constructing their identities using digital media (Tesis Doctoral), Universitat de Barcelona, Barcelona.

\section{NOTES}

1. Available in <https://rromanipativ.info/informe-anual/>.

2. See on: < https://rromanipativ.info/wp-content/uploads/2021/02/Uso-de-las-redes-socialespara-combatir-el-antigitanismo_digital-1.pdf>.

3. See on: <http://www.institutoromanoformacion.es/curso-estrategias/>.

\section{ABSTRACTS}

Social media such as Twitter and Facebook are currently sites where right-wing (political) groups in Spain find easy ways to spread organised and random hate speech towards minority groups, among which the Roma community. However, members of these groups, especially the younger generations, are rapidly learning how to protect themselves from racist and sexist online attacks, raise their voices and make their realities more visible, creating counter-narratives against hate speech and making the internet a safer space for themselves. This article presents the results of an action-research experience with young Roma women in Spain. Fifteen participants between 15 and 30 years old gathered for six online sessions during the Covid-19 pandemic, exchanging ideas and designing strategies to counter Antigypsyism online. The internet was not only the focus of the workshop, but also the main tool to carry it out. The project was informed by intersectional feminist thought, its main aim being to enable Romani women to deal with sexism and racism as a double axis of discrimination and online harrassment in Spain. In this article we will explain the methodology that was used and the topics, themes and insights that came up during the sessions, followed by some reflections on the process of designing and developing the workshop based on the theoretical discussions about Antigypsyim and social media in Spain.

Les médias sociaux tels que Twitter et Facebook sont actuellement des sites où les groupes (politiques) de droite en Espagne trouvent des moyens faciles de diffuser des discours de haine organisés et aléatoires à l'encontre des groupes minoritaires, parmi lesquels la communauté Rom. Cependant, les membres de ces groupes, en particulier les jeunes générations, apprennent rapidement à se protéger des attaques en ligne racistes et sexistes, à faire entendre leur voix et à rendre leurs réalités plus visibles, créant des contre-discours contre les discours de haine et faisant d'Internet un espace plus sûr pour eux-mêmes. Cet article présente les résultats d'une expérience de recherche-action auprès de jeunes femmes Roms en Espagne. Quinze participants âgés de 15 à 30 ans se sont réunis pour six sessions en ligne pendant la pandémie de Covid-19, échangeant des idées et concevant des stratégies pour contrer l'antitsiganisme en ligne. L'internet n'était pas seulement le point central de l'atelier, mais aussi le principal outil pour le mener à bien. Le projet s'inspirait d'une pensée féministe intersectionnelle, son objectif principal étant de permettre aux femmes Roms de faire face au sexisme et au racisme comme un double 
axe de discrimination et de harcèlement en ligne en Espagne. Dans cet article, nous expliquerons la méthodologie qui a été utilisée et les sujets, thèmes et idées qui ont été soulevés au cours des sessions, suivis de quelques réflexions sur le processus de conception et de développement de

l'atelier basé sur les discussions théoriques sur les antitsiganismes et les médias sociaux en Espagne.

INDEX

Keywords: Antigypsyism, Social Media, Hate Speech, Intersectionality, Media Literacy

\section{AUTHORS}

\section{CILIA WILLEM}

Universidad Rovira I Virgili

cilia.willem@urv.cat

\section{GABRIELA MARQUES GONÇALVES}

Miembro externo del Instituto de Comunicación (Incom-UAB) y Cátedra UNESCO de

Comunicación de la Universidad Autónoma de Barcelona y Profesora Sustituta de la Universidad Federal de Bahia (Brasil)

gmgjornal@gmail.com 